\title{
Seasonal variation in Azumiobodo hoyamushi infection among benthic organisms in the southern coast of Korea
}

\author{
Ki-Woong Nam¹, Yun-Kyung Shin² and Kyung-\| Park**
}

\begin{abstract}
Background: Recent studies have reported that soft tunic syndrome (STS) in the edible ascidian Halocynthia roretzi is caused by the kinetoplastid parasite Azumiobodo hoyamushi. In this study, we attempted to detect and quantify the pathogen in benthic animals.

Methods: Four species of ascidians, three species of echinoderms, two species of bivalves, one species each of sponge and algae, as well as seawater, were collected in 2014 and 2015 from an ascidian farm on the southern coast of Korea by SCUBA diving. Samples were collected from ascidian hanging culture ropes or the sea bottom. Inhalent siphons were excised for the analysis of ascidians, and soft body tissues were excised from the other species. Membrane filters were used to filter collected seawater. Tissues and membrane filters were analysed using culture testing, PCR testing, and $\mathrm{qPCR}$ diagnoses.

Results: Only organisms belonging to Ascidiacea are susceptible to A. hoyamushi infection. The infection rate (\% infected of the total number collected) and infection intensity (number of cells infected/g tissue wet weight) varied depending on the seasonal variation in seawater temperatures. Most ascidians examined were infected with A. hoyamushi and showed higher infection intensity in cold water seasons (April 2014 and February 2015), followed by a dramatic drop during warm water seasons (August and November, 2014). In addition, infection intensity of $A$. hoyamushi during the warm water period was higher in ascidians from the sea bottom than those from the hanging culture rope.

Conclusions: Among benthic organisms that inhabit the southern coast of Korea, most ascidians are susceptible to A. hoyamushi infection. Seasonal cycle of infection rates and intensities of the pathogen correspond well with the STS disappearance and onset cycle observed in ascidian farms. The high intensity of A. hoyamushi infection in the ascidians on the sea bottom of ascidian farms during summer suggest further studies on the role of the pathogen in resumption of STS occurrence in late fall or early winter in the southern coast of Korea.
\end{abstract}

Keywords: Benthic organisms, Soft tunic syndrome, Ascidiacea, Halocynthia roretzi, Azumiobodo hoyamushi

\section{Background}

Halocynthia roretzi represents an important species of Ascidiacea for the fishing industries of South Korea and Japan, and is produced by high-density culture $[1,2]$. However, in the early 1990 s, mass mortality of $H$. roretzi due to soft tunic syndrome (STS) occurred during winter and the following spring. Ascidian STS (AsSTS)

\footnotetext{
* Correspondence: kipark@kunsan.ac.kr

'Department of Aquatic Life Medicine, College of Ocean Science and Technology, Kunsan National University, 558 Daehakno, Gunsan 573-701, Republic of Korea

Full list of author information is available at the end of the article
}

has been occurring with comparable frequency in South Korea and Japan [3-6].

Kumagai et al. [7] isolated a flagellated parasite in STSdiseased $H$. roretzi cultured in Miyagi Prefecture in north eastern Japan and Hirose et al. [5] identified that flagellate as the causal agent of STS via challenge test, and named it as Azumiobodo hoyamushi. Meanwhile, Shin et al. [8] also reported flagellated parasites detected specifically in STSdiseased $H$. roretzi cultured in Tongyeong on the southern coast of South Korea. Kim et al. [9] identified these flagellated parasites as A. hoyamushi and indicated that AsSTS 
on the coasts of South Korea was caused by this pathogen, similar to Japan.

Kim et al. [9] reported that pure cultured A. hoyamush $i$ thrived at a water temperature range of $10-15{ }^{\circ} \mathrm{C}$, whereas temperatures outside this range caused reduced growth or death of $A$. hoyamushi. This indicates that water temperature is one of the factors that plays a major role in $A$. hoyamushi growth. Water temperatures along the southern coast of Korea vary greatly according to season, with the surface layer reaching more than $25^{\circ}$ $\mathrm{C}$ during summer (July to September) and falling below $10{ }^{\circ} \mathrm{C}$ during winter (January to February) [10]. Therefore, such water temperature differences are expected to induce seasonal variations in $A$. hoyamushi infection intensity in the tunics of $H$. roretzi.

In the present study, we collected a variety of benthic organisms that inhabit the waters around an ascidian farm during different seasons and quantitatively diagnosed $A$. hoyamushi in these organisms using molecular techniques. We examined the host range of $A$. hoyamush $i$ and seasonal variations in the rate and intensity of infection by $A$. hoyamushi.

\section{Methods}

\section{Sampling and analysis preparation}

Organisms attached to ascidian hanging culture lines and benthic organisms on the bottom of the ascidian farm were collected by SCUBA diving during April, August, and November 2014 and February 2015 from Bangaseom ascidian farm located in Tongyeong (south Gyeonsang Province, South Korea) (Fig. 1). Seawater samples were also collected from the site at depths of 1 and $12 \mathrm{~m}$ during each collection period. Collected samples were transported to the laboratory for measurements of size and body weight. For ascidian organisms, incurrent siphons were excised for use in the analysis, while soft body tissues were excised from the other species. Membrane filters ( $\Phi 0.2 \mu \mathrm{m}$, DISMIC-25AS, ADVANTEC, Japan) were used to filter $10 \mathrm{~L}$ of the collected seawater for $24 \mathrm{~h}$. All tissues and membrane filters were divided into three equal parts by weight and each sample was used for culture testing, PCR testing, and qPCR diagnoses.

\section{Culture testing}

Tissues excised from each sample were placed in minimum essential medium (MEM) and cultured for 5 days, followed by observation under a microscope to detect the presence of $A$. hoyamushi. Experimental procedures were performed in accordance with reported methodology [9].

\section{PCR test}

DNA from the excised tissues was extracted using DNA blood and tissue kit (Qiagen, Korea). The primer used in the PCR diagnosis was F: $5^{\prime}$-GCC TCT GTG GTT TGC TCC TT-3', R: 5'-TAC TGG GCG GCT TGG ATC TCG T-3' [9], and the PCR cocktail was prepared by admixing $0.25 \mu \mathrm{L}$ enzyme ( 5 units $/ \mu \mathrm{L}$, ExTaq ${ }^{\mathrm{Tw}}$, TaKaRa, Japan), $5 \mu \mathrm{L}$ buffer, $4 \mu \mathrm{L}$ dNTP mixture, 100 ng DNA template, and $0.2 \mu \mathrm{M}$ primer pair. Amplification of the $A$. hoyamushi-specific DNA sequence was performed

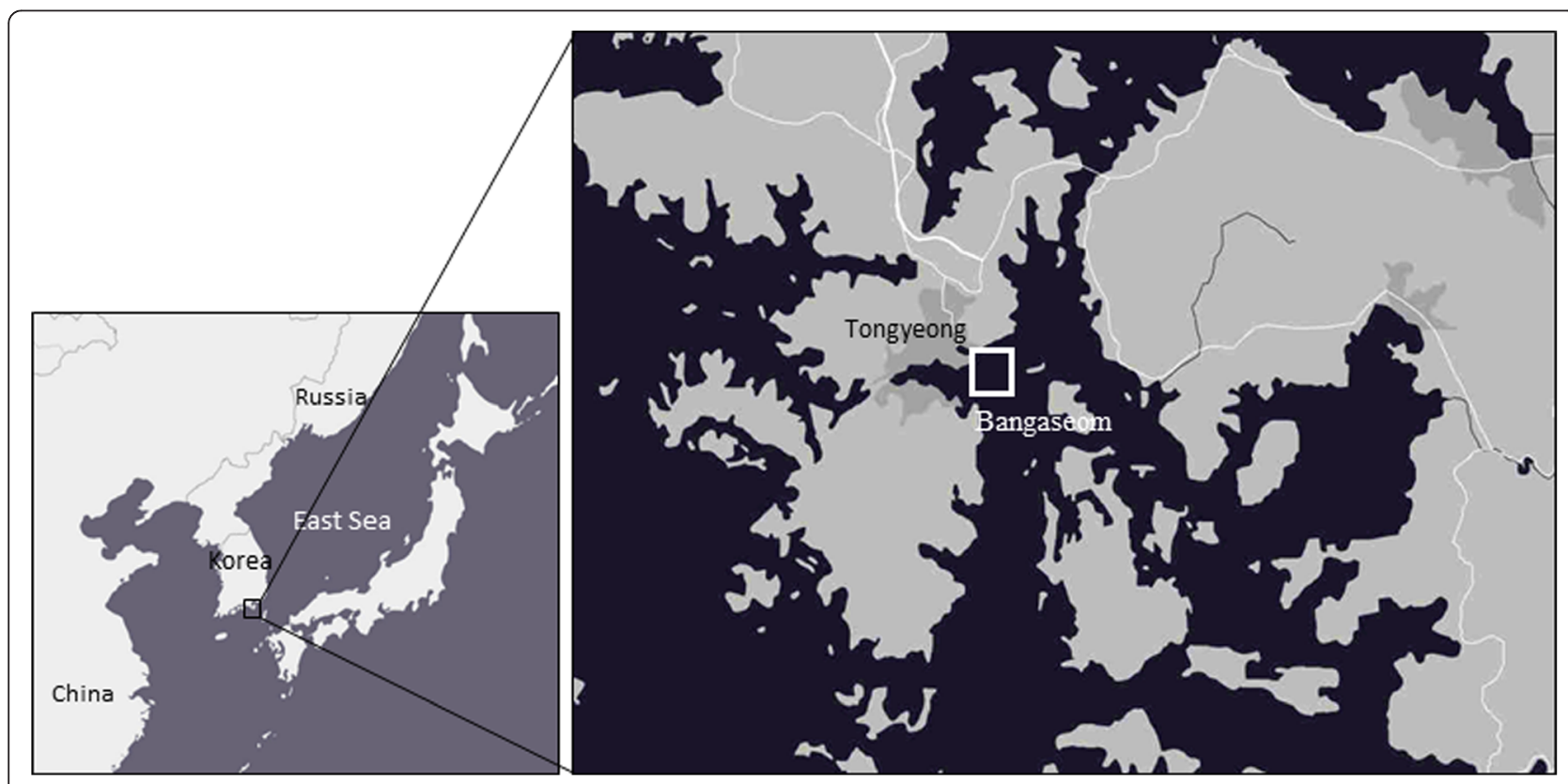

Fig. 1 Sampling location on the southern coast of Korea 
using a PCR system (GeneAmp PCR system 9700, Applied Biosystems, USA). The PCR conditions consisted of pre-denaturation at $94{ }^{\circ} \mathrm{C}$ for $5 \mathrm{~min}$, followed by 35 cycles of denaturation at $94{ }^{\circ} \mathrm{C}$ for $1 \mathrm{~min}$, annealing at $64{ }^{\circ} \mathrm{C}$ for $30 \mathrm{~s}$, and extension at $72{ }^{\circ} \mathrm{C}$ for $1 \mathrm{~min}$. For the PCR results, amplified products of 642 bp were confirmed by electrophoresis on a $1 \%$ agarose gel.

\section{qPCR}

After pulverization of $150 \mathrm{mg}$ of each sample, DNA was extracted using DNA blood kit (Qiagen) and $A$. hoyamush $i$ was quantified using the Taq-Man probe technique [11]. The primer used in the qPCR was F: $5^{\prime}-\mathrm{GCC}$ TCT GTG GTT TGC TCC TT-3', R: 5'-TAC TGG GCG GCT TGG ATC TCG T-3' and the probe was 5' FAM-CCG CTC AAA GAC GAA CTA CAG CGA -BHQ1 3'. Preparation of the qPCR cocktail consisted of adding template DNA, primer pair, probe, and distilled water to the premix (Bioneer, Korea) to bring it to a final volume of $20 \mu \mathrm{L}$, followed by amplification of the $A$. hoyamushi-specific DNA sequence using Exicycler ${ }^{\text {rm }} 96$ (Bioneer). The qPCR conditions were as follows: predenaturation at $94{ }^{\circ} \mathrm{C}$ for $5 \mathrm{~min}$, followed by 45 cycles of denaturation at $94{ }^{\circ} \mathrm{C}$ for $1 \mathrm{~min}$, annealing at $58{ }^{\circ} \mathrm{C}$ for
$30 \mathrm{~s}$, and extension at $72{ }^{\circ} \mathrm{C}$ for $1 \mathrm{~min}$, after which the reaction results were observed. Infection intensity was tested according to reported methodology [11]. Briefly, in vitro cultured $A$. hoyamush $i$ was diluted to $1,10,100$, 1000 , and 100,000 cells and the Ct value for each parasite concentration was obtained using real-time PCR. After deriving the correlation equation for the parasite concentration and $\mathrm{Ct}$ value, the $\mathrm{Ct}$ value confirmed from real-time PCR for the sample in question was substituted into this equation to quantify the results, which were expressed as the number of cells/g tissue wet weight.

\section{Results}

\section{Samples}

Samples included four species of ascidians, three species of echinoderms, two species of bivalves, one species of sponge, and one species of algae (Table 1). This distribution of species was similar for each sampling period. Ascidians attached to the ascidian hanging culture rope were identified as $H$. roretzi, Styela clava and Pyura vittata. Ascidians collected from the bottom of the ascidian farm were $H$. roretzi, S. clava, S. plicata and $P$. vittata. In addition to these, echinoderms Asterias

Table 1 Infection rates of Azumiobodo hoyamushi among benthic organisms on the southern coast of Korea, measured by cultivation of tissues in minimal essential media (MEM)

\begin{tabular}{|c|c|c|c|c|c|}
\hline \multirow{2}{*}{$\begin{array}{l}\text { Specimens } \\
\text { Tunicates }\end{array}$} & \multirow[b]{2}{*}{ Collection source } & \multicolumn{4}{|c|}{ Sampling period } \\
\hline & & Apr. 2014 & Aug. & Nov. & Feb. 2015 \\
\hline Halocynthia roretzi & Hanging rope & $30 \%(3 / 10)$ & $20 \%(2 / 10)$ & $20 \%(2 / 10)$ & $50 \%(5 / 10)$ \\
\hline Styela clava & Hanging rope & $20 \%(1 / 5)$ & - & $40 \%(4 / 10)$ & $60 \%(3 / 5)$ \\
\hline Pyura vittata & Hanging rope & - & $25 \%(1 / 4)$ & $100 \%(2 / 2)$ & $50 \%(1 / 3)$ \\
\hline Halocynthia roretzi & Bottom & - & $50 \%(5 / 10)$ & $20 \%(2 / 10)$ & $20 \%(2 / 10)$ \\
\hline Styela clava & Bottom & $0 \%(0 / 5)$ & $30 \%(3 / 10)$ & $0 \%(0 / 5)$ & $60 \%(3 / 5)$ \\
\hline Styela plicata & Bottom & - & $25 \%(1 / 4)$ & $0 \%(0 / 5)$ & $60 \%(3 / 5)$ \\
\hline Pyura vittata & Bottom & - & $100 \%(2 / 2)$ & - & $50 \%(1 / 2)$ \\
\hline \multicolumn{6}{|l|}{ Echinoderms } \\
\hline Asterias amurensis & Bottom & $0 \%(0 / 5)$ & $0 \%(0 / 5)$ & $0 \%(0 / 5)$ & $0 \%(0 / 5)$ \\
\hline Asterina pectinifera & Bottom & $0 \%(0 / 5)$ & $0 \%(0 / 1)$ & $0 \%(0 / 5)$ & $0 \%(0 / 5)$ \\
\hline Luidia quinaria & Bottom & - & $0 \%(0 / 5)$ & - & $0 \%(0 / 1)$ \\
\hline \multicolumn{6}{|l|}{ Bivalves } \\
\hline Mytilus galloprovincialis & Bottom & $0 \%(0 / 5)$ & $0 \%(0 / 5)$ & $0 \%(0 / 5)$ & $0 \%(0 / 2)$ \\
\hline Atrina pectinata & Bottom & - & $0 \%(0 / 3)$ & - & $0 \%(0 / 1)$ \\
\hline \multicolumn{6}{|l|}{ Sponge } \\
\hline Unknown & Bottom & - & - & $0 \%(0 / 5)$ & $0 \%(0 / 5)$ \\
\hline \multicolumn{6}{|l|}{ Algae } \\
\hline Undaria pinnatifida & Bottom & $0 \%(0 / 5)$ & $0 \%(0 / 1)$ & - & $0 \%(0 / 1)$ \\
\hline \multicolumn{6}{|l|}{ Seawater } \\
\hline \multirow[t]{2}{*}{ Seawater } & Surface & $100 \%(1 / 1)$ & $0 \%(0 / 1)$ & $0 \%(0 / 1)$ & $0 \%(0 / 1)$ \\
\hline & Bottom & $100 \%(1 / 1)$ & $0 \%(0 / 1)$ & $0 \%(0 / 1)$ & $0 \%(0 / 1)$ \\
\hline
\end{tabular}


amurensis, A. pectinifera and Luidia quinaria and bivalves Mytilus galloprovincialis and Atrina pectinata were collected from the bottom of the ascidian farm. One species each of sponge and algae were also collected. Water temperatures at $1 \mathrm{~m}$ depth in 2014 were 15, 25 and $19{ }^{\circ} \mathrm{C}$ in April, August, and November, respectively, and dropped to $9{ }^{\circ} \mathrm{C}$ in February 2015. Water temperatures at $12 \mathrm{~m}$ depth in 2014 were 15, 21 and $19^{\circ} \mathrm{C}$ in April, August, and November, respectively, and dropped to $9{ }^{\circ} \mathrm{C}$ in February 2015. These water temperatures were almost within the range of variation in water temperature for each month recorded by KOOFS during the same period as our study [12].

\section{Culture test}

Azumiobodo hoyamushi infection, confirmed via a culture test, was found only in ascidians and was not detected in the echinoderms, bivalves, sponge, or algae (Table 1). Confirmed A. hoyamushi infection in $H$. roretzi on the ascidian hanging culture rope was detected throughout the investigation period, with infection rates decreasing from $30 \%$ in April to $20 \%$ in August and November, then rising to $50 \%$ the following February. In August, $50 \%$ of $H$. roretzi collected from the sea bottom were infected, decreasing to $20 \%$ in November and the following February. Among other ascidians collected from the bottom of the ascidian farm, 0-20\% were infected during April and November 2014, increasing to $20-60 \%$ the following February. In seawater samples, A. hoyamushi was detected only in April.

\section{PCR testing}

The PCR test also revealed $A$. hoyamushi infection only in ascidians, similar to the culture test. Seasonal variation in infection rates showed an overall pattern of abundance in April, decreasing in August, increasing again in November, and maintaining the rate until the following February (Table 2). In April, $90 \%$ of H. roretzi from hanging culture ropes were infected. In August, $20 \%$ were infected, followed by an increase to $80 \%$ in November, which was then maintained at about $60 \%$ until the following February. Halocynthia roretzi was not collected from the sea bottom in April; however, about $50 \%$ of those collected in August were infected, whereas in November and the following February, A. hoyamushi infection was found in all individuals. In samples of $S$. clava attached to the hanging culture rope, 40-100\%

Table 2 Infection rates of Azumiobodo hoyamushi among benthic organisms on the southern coast of Korea, measured by PCR

\begin{tabular}{|c|c|c|c|c|c|}
\hline \multirow[t]{2}{*}{ Specimens } & \multirow[b]{2}{*}{ Collection source } & \multicolumn{4}{|c|}{ Sampling period } \\
\hline & & Apr. 2014 & Aug. & Nov. & Feb. 2015 \\
\hline \multicolumn{6}{|l|}{ Tunicates } \\
\hline Halocynthia roretzi & Hanging rope & $90 \%(9 / 10)$ & $20 \%(2 / 10)$ & $80 \%(8 / 10)$ & $60 \%(6 / 10)$ \\
\hline Styela clava & Hanging rope & $100 \%(5 / 5)$ & - & $40 \%(4 / 10)$ & $60 \%(3 / 5)$ \\
\hline Pyura vittata & Hanging rope & - & $25 \%(1 / 4)$ & $100 \%(2 / 2)$ & $100 \%(3 / 3)$ \\
\hline Halocynthia roretzi & Bottom & - & $50 \%(5 / 10)$ & $60 \%(6 / 10)$ & $60 \%(6 / 10)$ \\
\hline Styela clava & Bottom & $0 \%(0 / 5)$ & $30 \%(3 / 10)$ & $60 \%(3 / 5)$ & $60 \%(3 / 5)$ \\
\hline Styela plicata & Bottom & - & $50 \%(2 / 4)$ & $60 \%(3 / 5)$ & $80 \%(4 / 5)$ \\
\hline Pyura vittata & Bottom & - & $100 \%(2 / 2)$ & - & $50 \%(1 / 2)$ \\
\hline \multicolumn{6}{|l|}{ Echinoderms } \\
\hline Asterias amurensis & Bottom & $0 \%(0 / 5)$ & $0 \%(0 / 5)$ & $0 \%(0 / 5)$ & $0 \%(0 / 5)$ \\
\hline Asterina pectinifera & Bottom & $0 \%(0 / 5)$ & $0 \%(0 / 1)$ & $0 \%(0 / 5)$ & $0 \%(0 / 5)$ \\
\hline Luidia quinaria & Bottom & - & $0 \%(0 / 5)$ & - & $0 \%(0 / 1)$ \\
\hline \multicolumn{6}{|l|}{ Bivalves } \\
\hline Mytilus galloprovincialis & Bottom & $0 \%(0 / 5)$ & $0 \%(0 / 5)$ & $0 \%(0 / 5)$ & $0 \%(0 / 2)$ \\
\hline Atrina pectinata & Bottom & - & $0 \%(0 / 3)$ & - & $0 \%(0 / 1)$ \\
\hline \multicolumn{6}{|l|}{ Sponge } \\
\hline Unknown & Bottom & - & - & $0 \%(0 / 5)$ & $0 \%(0 / 5)$ \\
\hline \multicolumn{6}{|l|}{ Algae } \\
\hline Undaria pinnatifida & Bottom & $0 \%(0 / 5)$ & $0 \%(0 / 1)$ & - & $0 \%(0 / 1)$ \\
\hline \multicolumn{6}{|l|}{ Seawater } \\
\hline \multirow[t]{2}{*}{ Seawater } & Surface & $100 \%(1 / 1)$ & $0 \%(0 / 1)$ & $0 \%(0 / 1)$ & $0 \%(0 / 1)$ \\
\hline & Bottom & $100 \%(1 / 1)$ & $0 \%(0 / 1)$ & $0 \%(0 / 1)$ & $0 \%(0 / 1)$ \\
\hline
\end{tabular}


were infected. In S. clava samples collected from the bottom of the ascidian farm, no individual was infected in April, $30 \%$ were infected in August, and $60 \%$ were infected in November as well as in the following February. Most of the $P$. vittata individuals attached to the hanging culture ropes and those inhabiting the sea bottom were also infected.

\section{qPCR}

Quantification of $A$. hoyamushi using real-time PCR showed that infection intensity in $H$. roretzi from the rope culture averaged to 889.13 cells/g in April. The infection intensity decreased rapidly to 66.25 cells/g by August, continued to decrease to $41.70 \mathrm{cells} / \mathrm{g}$ in November, then drastically increased to 1858.07 cells/g by the following February (Fig. 2). Infection intensity of A. hoyamushi in $H$. roretzi found on the bottom of the ascidian farm was 115.12 cells/g in August and 201.10 cells/g in November, increasing rapidly to 1323.55 cells/ $\mathrm{g}$ by the following February. The changes in infection intensity in S. clava and P. vittata were similar to those in $H$. roretzi. Samples of $S$. plicata were collected only from the bottom of the ascidian farm and $A$. hoyamushi infection intensities in August and November were similar to those of other ascidians. However, in February 2015, 1984.38 cells/g were recorded. In seawater, infection intensities of $A$. hoyamushi were 28.37 cells/g at $1 \mathrm{~m}$ depth and 32.72cells/g at $12 \mathrm{~m}$ depth.

\section{Discussion}

In the present study, we investigated the prevalence and infection intensity of $A$. hoyamushi using tissue culture method and molecular techniques. In particular, the inhalent tissue of ascidians was removed and used for quantification of the pathogen. Shin et al. [11] examined

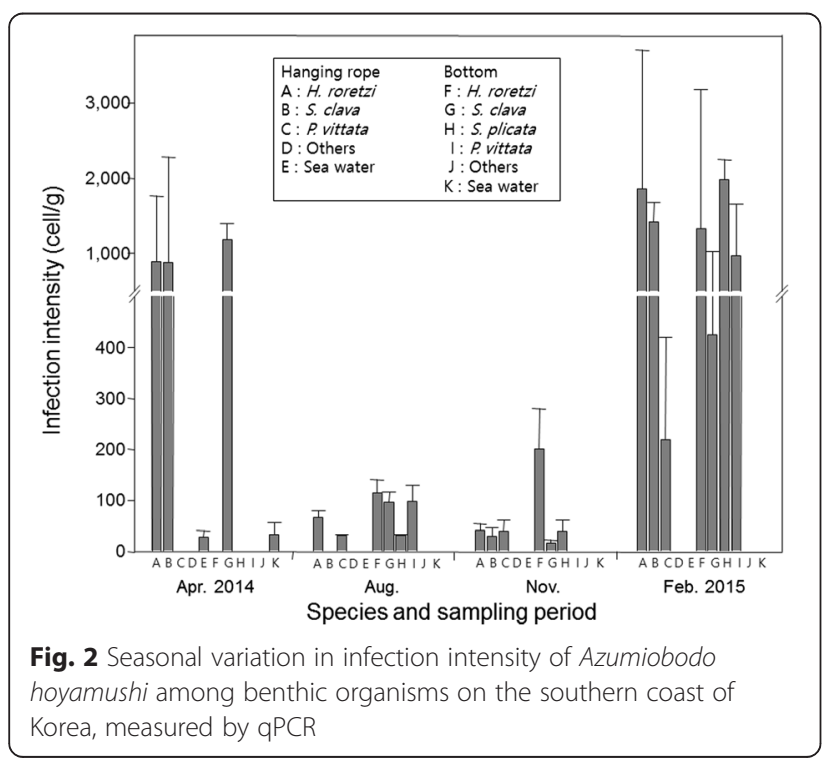

the infection intensity of $A$. hoyamushi in various parts of the tunic, including inhalent siphon, exhalent siphon, and three different parts of the tunic; they found that the inhalent siphon was the most sensitive organ for the diagnosis of the pathogen. They also reported that infection intensity of $A$. hoyamushi increased as STS developed and the pathogens spread to other parts of the tunic from the inhalent siphon. Hirose et al. [12] also reported that the inhalent siphon of $H$. roretzi is the point of entry of $A$. hoyamushi. Therefore, the inhalent siphon tissue is regarded as the best tissues for the quantitative measurement of $A$. hoyamush $i$ in ascidians.

Approximately 20 species of ascidians have been reported to inhabit the waters of South Korea, of which five species are edible $[2,13]$. As observed in the present study, A. hoyamushi infections were confirmed in $H$. roretzi, S. clava, S. plicata, and $P$. vittata. With the exception of $P$. vittata, these species are produced commercially on the southern coast of Korea by high-density culture. In most of these species, $A$. hoyamushi infection rates exceeded $50 \%$ in the PCR test results and infection intensities were confirmed to reach tens to thousands of individuals per gram of host tissue. With such broad occurrence in ascidians, the high infection rates and intensities discovered in this study are proposed to enhance opportunities for interspecific $A$. hoyamushi infection within ascidians and are believed to be the cause of the continued occurrence of AsSTS in ascidian farms. Kumagai et al. [14] also reported that $S$. clava is a potential carrier of $A$. hoyamushi in ascidians. According to a recent report [15], mass death of $S$. clava has been seen during summer seasons in Tongyeong, with the primary symptom being softening of the body, a symptom that is similar to AsSTS. Generally, AsSTS is not known to occur frequently during summer seasons [16]. However, given that symptoms seen during $S$. clava mass death were similar to those of STS, and that A. hoyamushi infections occur during summer, as confirmed in the present study, investigations of the influence of $A$. hoyamushi on S. clava mass death should be undertaken.

Seasonal variation in $A$. hoyamushi infection rates showed a pattern of being low during summer and increasing during winter or spring. A more prominent seasonal variability was seen in infection intensity, reaching 1000 cells/g or more in $H$. roretzi, S. clava, and $P$. vittata in April 2014 and decreasing to less than 100 cells/g in August. Such patterns continued until November; however, by the following February, infection intensity increased to the level of the previous April. Seasonal changes in $A$. hoyamushi infection intensity in $H$. roretzi appear to be based on seasonal variations in water temperature. According to Kim et al. [9], A. hoyamushi showed the highest growth rate at $15{ }^{\circ} \mathrm{C}$, and conversely, at temperatures below $10{ }^{\circ} \mathrm{C}$ or above $20{ }^{\circ} \mathrm{C}$, growth 
reduced or led to death. The relationship between water temperature and $A$. hoyamushi infection intensity was similar to that between water temperature and $A$. hoyamushi growth reported previously [9]. Therefore, the present study strongly suggests that the year-round variation in $A$. hoyamushi infection intensity in $H$. roretzi from ascidian farms is determined by water temperature. In ascidian farms, AsSTS disappears during summer seasons and reoccurs during early winter seasons [2, 17]. Thus, it appears that $A$. hoyamushi infection intensity decreases as water temperature rises in summer, whereas infection intensity increases as water temperature drops.

Azumiobodo hoyamushi infection rate and intensity also varied according to water depth. Infection rate and intensity were drastically higher in wild ascidians inhabiting the seabed of the ascidian farm (water depth of $12 \mathrm{~m}$ ) during summer (August), when STS decreased, than in ascidians attached to hanging culture rope (water depth of $1 \mathrm{~m}$ ). This is likely because most of the parasites on the surface layer had died, given that the water temperature on the surface layer had reached $25{ }^{\circ} \mathrm{C}$ at the time of collection of samples. The temperature at the bottom layer of the ascidian farm reached only $21^{\circ}$ $\mathrm{C}$, a lower water temperature is associated with a lower A. hoyamushi mortality rate, leading to the survival of more number of parasites than that in the upper layer. Thus, conditions in the bottom layer enabled A. hoyamushi to survive inside ascidian organisms inhabiting the bottom, although STS disappeared from ascidians in the hanging culture ropes due to the high water temperature. It is suggested that surviving parasites in ascidians on the sea bottom were then able to infect new hosts attached to ascidian hanging culture ropes when the water temperature dropped in winter. Meanwhile, Nawata et al. [18] suggested the role of cysts of the pathogen. According to the study, cyst-like cells of $A$. hoyamushi can survive on the sea bottom at high temperatures, followed by excystment in the host at low water temperatures.

\section{Conclusions}

Among benthic organisms that inhabit the southern coast of Korea, A. hoyamushi was detected only in ascidians, and most of the ascidians sampled were infected by A. hoyamushi. Infection rates and intensities showed a seasonal cycle of reduction during summer, when the water temperature is high, and abundance during seasons when the water temperature is low. Infection rates and intensities also varied according to water depth. It is believed that warmer surface temperatures led to death of the parasites, whereas deeper, cooler water allowed survival of a number of parasites in the ascidians at the bottom of the sea. High occurrence of $A$. hoyamushi on the sea bottom suggest additional studies on the role of the pathogens for resumption of STS occurrence in late fall or early winter on the southern coast of Korea.

\section{Competing interests}

The authors declare that they have no competing interests.

\section{Authors' contributions}

KWN and KIP formulated the idea and wrote the manuscript; KWN performed the analysis processes. KIP and YKS provided critical comments to the methods and the discussion. All authors approved the final version of this manuscript.

\section{Acknowledgments}

This work was financially supported by the National Fisheries Research and Development Institute of Korea (NFRDI, RP-2015-AQ-038). We also thank the Marine Biology Education Center of the Kunsan National University for providing ascidian culture facilities during the experiment.

\section{Author details}

${ }^{1}$ Department of Aquatic Life Medicine, College of Ocean Science and Technology, Kunsan National University, 558 Daehakno, Gunsan 573-701, Republic of Korea. ${ }^{2}$ National Fisheries Research Institute, Busan 619-705, Republic of Korea.

Received: 14 October 2015 Accepted: 23 October 2015

Published online: 04 November 2015

\section{References}

1. Korean statistical information service: Census of fisheries database. http:// kosis.kr (2014). Accessed 10 Aug 2015.

2. Kim W-J, Lee $\mathrm{Cl}$, Kim HS, Han HS, Jee Y-J, Kong HJ, et al. Population genetic structure and phylogeography of the ascidian, Halocynthia roretzi, along the coasts of Korea and Japan, inferred from mitochondrial DNA sequence analysis. Biochem Syst Ecol. 2012;44:128-35.

3. Kumagai A, Suto A, Ito H, Tanabe T, Takahashi K, Kamaishi T, et al. Mass mortality of cultured ascidians Halocynthia roretzi associated with softening of the tunic and flagellate-like cells. Dis Aquat Org. 2010;90:223-34.

4. Hirose E, Ohtake SI, Azumi K. Morphological characterization of the tunic in the edible ascidian, Halocynthia roretzi (Drasche), with remarks on 'soft tunic syndrome' in aquaculture. J Fish Dis. 2009;32:433-45.

5. Hirose E, Nozawa A, Kumagai A, Kitamura SI. Azumiobodo hoyamushi gen. nov. et sp. nov. (Euglenozoa, Kinetoplastea, Neobodonida): a pathogenic kinetoplastid causing the soft tunic syndrome in ascidian aquaculture. Dis Aquat Org. 2012;97:227-35.

6. Cha IS, Castillo CS, Nho SW, Hikima J-I, Aoki T, Jung TS. Innate immune response in the hemolymph of an ascidian, Halocynthia roretzi, showing soft tunic syndrome, using label-free quantitative proteomics. Dev Comp Immunol. 2011;35:809-16.

7. Kumagai A, Suto A, Ito H, Tanabe T, Song JY, Kitamura SI, et al. Soft tunic syndrome in the edible ascidian Halocynthia roretzi is caused by a kinetoplastid protist. Dis Aquat Org. 2011;95:153-61.

8. Shin Y-K, Kim H-J, Park K-I, Choi M-S, Jun J-C, Kim E-O. Occurrence of bi-flagellated protists in the tunics of ascidians Halocynthia roretzi with tunic-softness syndrome collected from Tongyeong, south coast of Korea. J Korean Fish Pathol. 2011;24:197-204. In Korean with English abstract.

9. Kim H-J, Park JS, Park KH, Shin Y-K, Park K-I. The kinetoplastid parasite Azumiobodo hoyamushi, the causative agent of soft tunic syndrome of the sea squirt Halocynthia roretzi, resides in the East Sea of Korea. J Invertebr Pathol. 2014;116:36-42

10. Korea Ocean Observing and Forecasting System. Korea Hydrographic and Oceanographic Administration, Busan, Korea http://sms.khoa.go.kr/koofs/ eng/observation/obs_real_map.asp Accessed 10 Oct 2015

11. Shin Y-K, Nam K-W, Park KH, Yoon J-M, Park K-I. Quantitative assessment of Azumiobodo hoyamushi distribution in the tunic of soft tunic syndromeaffected ascidian Halocynthia reretzi using real-time polymerase chain reaction. Parasit Vectors. 2014. doi:10.1186/s13071-014-0539-x.

12. Hirose E, Kumagai A, Nawata A, Kitamura S-I. Azumiobodo hoyamushi, the kinetoplastid causing soft tunic syndrome in ascidians, may invade through the siphon wall. Dis Aquat Org. 2014;109:251-6.

13. Kitamura S-I, Ohtake S-I, Song J-Y, Jung S-J, Oh M-J, Choi B-D, et al. Tunic morphology and viral surveillance in diseased Korean ascidians: soft tunic 
syndrome in the edible ascidian, Halocynthia roretzi (Drasche), in aquaculture. J Fish Dis. 2010;33:153-60.

14. Kumagai A, Sakai K, Miwa S. The sea squirt Styela clava is a potential carrier of the kinetoplastid Azumiobodo hoyamushi, the causative agent of soft tunic syndrome in the edible ascidian Halocynthia roretzi. Fish Pathol. 2014;49:206-9.

15. Jeon C-Y, Hur Y-B, Lee D-C. Results of the survey on the mass mortality of invasive sea squirt, styela clava, around Gosung area, on the southern coast of Korea. In: NFRDI, editor. Survey report of the causative agents of the mass mortalities of marine aquaculture species on the southern coast of Korea. Tong-young: NFRDI; 2012. p. 94-100.

16. NFRDI. The studies on stability of cultured sea squirt aquaculture fisheries. Seoul: NFRDI; 2009

17. Shin Y-K, Park J-J, Myeong J-I, Kim H-J, Lee J-S. Induction of soft tunic syndrome by water temperature and physiological and hitological responses of the sea squirt, Halocynthia roretzi. Kor J Environ Biol. 2014;32:225-33.

18. Nawata A, Hirose E, Kitamura S, Kumagai A. Encystment and excystment of kinetoplastid Azumiobodo hoyamushi, causal agent of soft tunic syndrome in ascidian aquaculture. Dis Aquat Org. 2015;115:253-62.

\section{Submit your next manuscript to BioMed Central and take full advantage of:}

- Convenient online submission

- Thorough peer review

- No space constraints or color figure charges

- Immediate publication on acceptance

- Inclusion in PubMed, CAS, Scopus and Google Scholar

- Research which is freely available for redistribution 